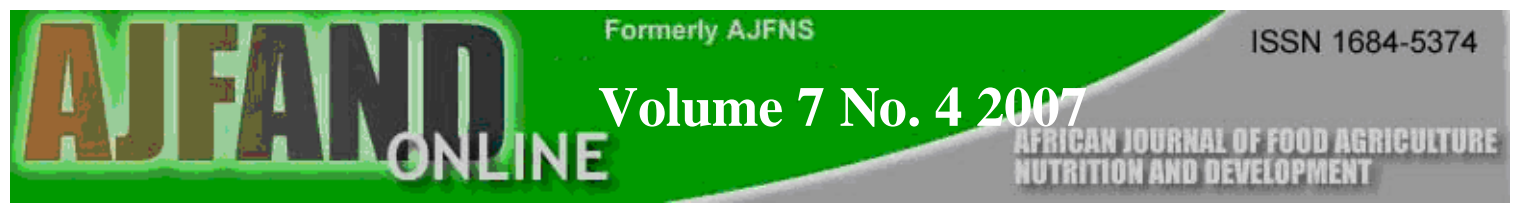

\title{
Taxonomic Identification and Characterization of African Nightshades (Solanum L. Section Solanum)
}

\section{By}

Gideon Njau Mwai ${ }^{* 1}$ John Collins Onyango ${ }^{1}$ and Mary O. Abukusta-Onyango ${ }^{1}$
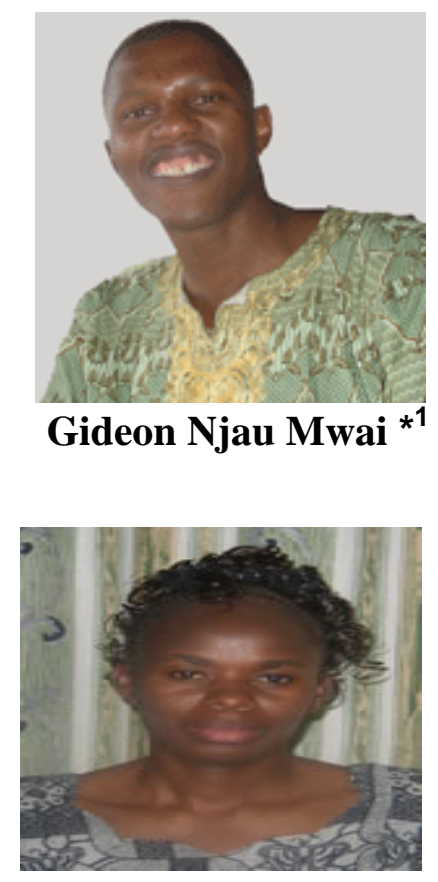

Mary O. Abukusta-Onyango ${ }^{1}$

*Corresponding author Email: mwaign@yahoo.com

1Department of Botany and Horticulture, Maseno University

P.O. Private Bag, 40105 Maseno, Kenya 


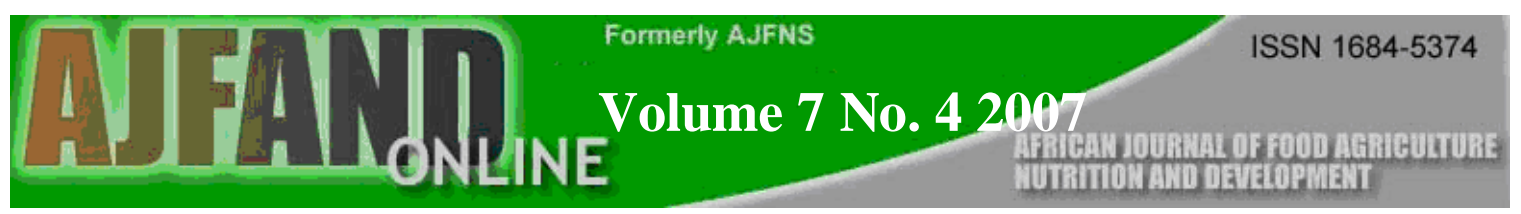

\section{ABSTRACT}

African nightshades play an important role in meeting the nutritional needs of rural households, and are reported as being particularly rich in protein, vitamin A, iron and calcium. Nightshades are among three top priority African indigenous vegetables identified for improvement and promotion through research. A major constraint facing this objective is the scantiness of taxonomic and nomenclatural knowledge on African nightshades resulting in extensive synonymy and confusion. As a consequence, the toxic species are difficult to discriminate from those with high nutritional value. It is also difficult to identify species with good agronomic traits for genetic enhancement. This study was conducted to identify, characterize, and delimit African nightshade species. Fifty accessions of Solanum section Solanum from eastern, southern and western Africa were raised in a greenhouse at the Botanical and Experimental Garden, Radboud University, Nijmegen, the Netherlands. A descriptor list with 48 vegetative and reproductive characters was developed and used to characterize flowering and fruiting plants. Counting of chromosome was done on root squash preparations from one weekold seedlings, aided by digital enhancement of microscopic images. Nine species were represented in the study material, including two diploids: Solanum americanum, and Solanum chenopodioides; five tetraploids: Solanum retroflexum, Solanum villosum, Solanum florulentum, Solanum grossidentatum and Solanum tarderemotum; and two hexaploids: Solanum nigrum and Solanum scabrum. Most of the section Solanum species were distinguishable and easily identified. The exception was $S$. florulentum and S. tarderemotum which were identified tentatively and assigned respective names, but are difficult to differentiate and require further studies. The $S$. florulentum/tarderemotum group has three distinguishable variants and further studies are needed to determine the taxonomic status of each as a separate species, subspecies or genotypic/phenotypic variants. Furthermore, S. retroflexum, S. villosum and $S$. scabrum each had a high degree of within-species variation, and further studies are recommended to determine whether the variations within each constitute subspecies.

Key words: Solanum sp., Identification, Characterization 


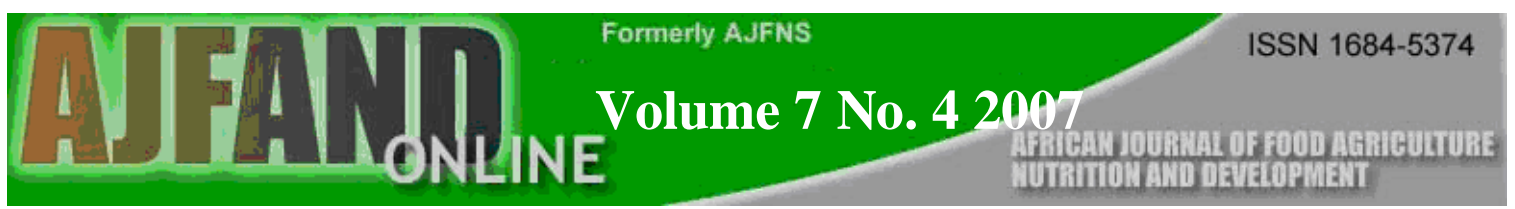

\section{INTRODUCTION}

Africa is richly endowed with plant genetic resources, with many well-adapted indigenous food crops that have long been grown on the continent. These crops play an important role in the food security of many resource poor farming families, and have potential value as a genetic resource for the global community $[1,2]$. Hence it is sad that African researchers, policy-makers and farmers have neglected the potential of these crops in reducing food insecurity and poverty. Leafy vegetables, including several African Indigenous Vegetables (AIVs), are highly valued in the typical African diet as accompaniment to carbohydrate-based staples $[3,4]$.

Concerns regarding agrobiodiversity use and conservation, coupled with poverty alleviation have greatly contributed to reawakened interest in AIVs. It is increasingly recognized that communitites are, almost exclusively, the custodians of knowledge on how AIVs are grown and used, as well as their cultural value and genetic diversity. The best way to reduce the threat of loss of AIVs biodiversity is to improve their conservation through increased production and utilization, and improve their productivity in order to make them more competitive with exotics [1 - 5].

Although nightshades are historically considered inedible poisonous plants or troublesome agronomic weeds in Europe and the Americas [6-8], their status is completely different in western, eastern and southern Africa as well as in India, Indonesia and China, where they have for long been used as leafy herbs and vegetables, as a source of fruits and dye, and for various medicinal uses [7-9]. In Kenya, black nightshades occur in many areas where they are known by a variety of local names such as managu (Kikuyu), ndulu (Kamba), osuga (Luo), lisutsa (Luhya), rinagu (Kisii), mnavu (Giriama), ksoyo (Pokot), kisochot (Elgeyo). They are often cultivated in small kitchen gardens, and occasionally collected from the wild for domestic use and sale in markets [10]. These vegetables play an important role in meeting the nutritional needs of rural households, being particularly rich in protein (especially the amino acid methionine, which is rarely found in plants), vitamin A, iron and calcium. Medicinally, they are used for stomach upsets, duodenal ulcers, swollen glands and teething problems [7, 8].

Vegetable nightshades are among the three top priority AIVs identified for further research and development due to their potential role in improving the nutritional and economic status of marginalized and poor rural, urban and peri-urban populations [2, 3]. Recent studies in East Africa have revealed increased use of AIVs and decreased use of exotics (cabbage, kale, spinach), mainly because AIVs require lower inputs to produce compared to exotics and consequently are more affordable for many rural households in the low-income bracket. AIVs are 


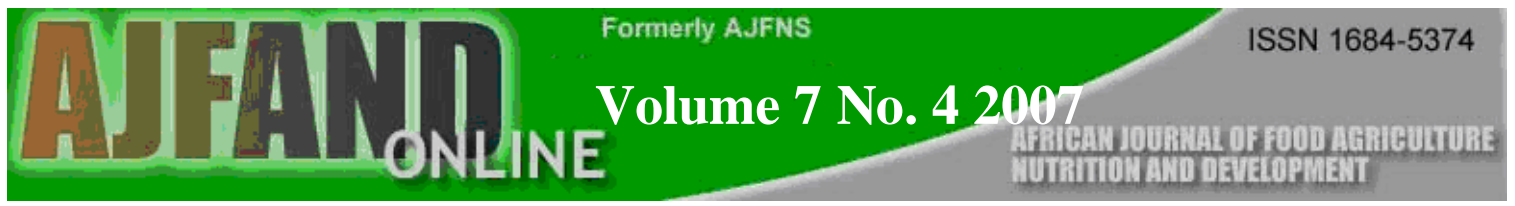

easily available and cheap in village markets, but expensive in under-supplied urban markets, indicating that they have potential to become commercially important and increase their market share $[9,11]$.

The nightshades comprise a group of approximately 30 species making up section Solanum of the genus Solanum; constituting a large number of closely related morphogenetically distinct taxa, and typified by the true black nightshade, Solanum nigrum L. [12]. This section is among the largest and most variable groups in the genus Solanum, with species that are distributed from temperate to tropical regions and from sea level to altitudes above 3500 meters [8]. Nightshades grow well under high moisture conditions, rainfall about $1500 \mathrm{~mm}$, and temperature between $20-30^{\circ} \mathrm{C}$. They do well in fertile soils that are rich in nitrogen, phosphorus, and high organic matter content [7].

Nightshades taxonomy has long been beleaguered by complexity, resulting in extensive synonymy and confusion [6, 13]. The causes for such complexity include historical reasons, phenotypic plasticity, genetic variation, polyploidy, natural hybridization and discordant variation [12]. Much of this complexity has been resolved for Europe, Asia, the Americas and Australia, leaving Africa and South-East Asia as the two major geographic regions where a comprehensive taxonomic treatment of the section is lacking $[6,8,12,14,15]$. Taxonomic resolution is necessary not only for effective biodiversity conservation, but also to understand the economic potential and opportunities that might accrue from these genetic resources. Consequently, Edmonds and Chweya [8] recognized the need for taxonomic studies using living African germplasm to supplement the previous work of several authors who mainly used herbarium material [16-18].

The toxic and medicinal properties of $S$. nigrum have been documented from early times [8]. All nightshades are known to contain solanine and other related glyco-alkaloids, as well as high levels of nitrate-nitrogen. Consequently, consumption of some nightshades reportedly causes stomach problems, indicating potential toxicity [3]. Due to the previously mentioned lack of adequate taxonomic resolution of the African taxa, it is difficult to identify the taxa containing high levels of toxins, as well as those with good agronomic traits for genetic enhancement. Consequently, popularization and genetic enhancement of these otherwise nutritionally rich vegetables has been hindered.

\section{OBJECTIVES}

The goal of this study was to address taxonomic complexity using nightshade germplasm collected in eastern, southern and western Africa. Specific objectives of the study were to characterize accessions of Solanum section Solanum from 


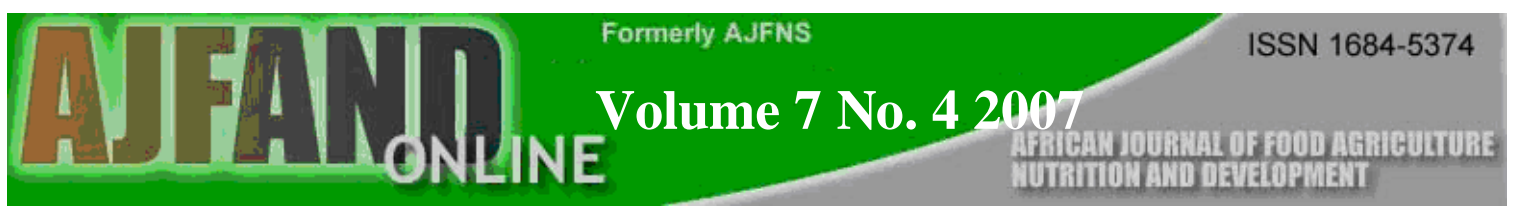

eastern, southern and western Africa; and to identify and delimit Solanum section Solanum species represented in the collection.

\section{MATERIALS AND METHODS}

Fifty accessions of African nightshades from eastern, western and southern Africa were raised in pots filled with vermiculite and peat soil under standard greenhouse conditions at the Botanical and Experimental Garden, Radboud University Nijmegen, The Netherlands. The strategy adopted was to use morphological and cytological (chromosome counts) characters of the living material to distinguish accessions belonging to different species and ploidy levels.

\section{Descriptor list}

An initial descriptor list was developed, including all morphological characters described by Edmonds and Chweya [8]. The resultant descriptor list was revised several times to cover the variation observed to occur in the plants growing in the greenhouse at the time of this study, culminating in a final version with 48 morphological characters. Character states were determined for each descriptor to represent the whole range of variation observed in the growing plants.

\section{Scoring for morphological characters}

Scoring for 47 (except chromosome counts) morphological characters was done according to the final version of the descriptor list on flowering and fruiting plants. Hair-type characters were scored with a magnifier and the presence or absence of stone cells in mature berries was checked in all the 50 accessions. Characters were scored based on either a majority of plants (qualitative) or mean of 10 random measurements (quantitative). Data were entered into computer in form of a matrix of character states; and cluster analysis done using NT-SYS software, using SIMQUAL (similarities for qualitative data) with UPGMA and simple matching and SAHN (sequential agglomerative hierarchical clustering).

\section{Chromosome counts}

Fresh seeds of the 50 accessions were sown in vermiculite-filled pots. One week after seedling emergence, root tips were obtained and fixed in $50 \%$ acetic acid for ten minutes; digested in 10\% hydrochloric acid for five minutes; placed on a microscope slide and stained with two drops of Fuchsin dye. Stained tips were allowed to stand for three to five minutes, then washed with $45 \%$ acetic acid and excess dye blotted with tissue paper and mounted in a drop of $45 \%$ acetic acid. A cover slip put on and the root tip squashed by tapping on the cover slip gently to 


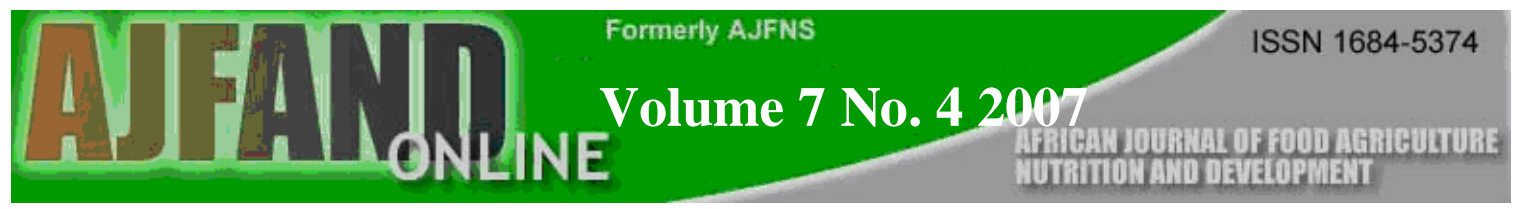

spread the root tip, taking care not to scatter cells too widely. Prepared slides were preserved by applying nail varnish around the cover slip and stored at $4^{\circ} \mathrm{C}$ until observation under compound microscope. Counting of the chromosomes was done by selecting cell plates at the late anaphase/early metaphase or late metaphase/early telophase stage of mitosis, in which chromosomes were properly condensed and well spread out such that individual chromosomes were easy to distinguish and count. Microscopic images were digitally enhanced to expedite the counting.

\section{RESULTS}

Nine Solanum section Solanum were represented in the 50 African accessions, spread across three out of the four known ploidy levels. There were two diploid species, five tetraploid species and two hexaploid species (Figure 1, Table 1). Below are detailed descriptions of each of the nine species represented in this study as observed on greenhouse-grown plants. Distinctive characteristics of each species are highlighted (Table 2).

\section{Solanum americanum Miller}

Plants: up to $1.3 \mathrm{~m}$ high with erect well developed tertiary branches. Stem: and nodes purplish green in color, glabrous and without wings. Leaves: ovatelanceolate with entire margins, acute apex, and green veins or light purple; veins occasionally with purplish tinge, glabrous, petiolate with petioles winged all the way, blade length $2 x$ blade width and $2 x$ petiole length. Fruiting peduncle: facing upward, $2 x$ as long as fruiting pedicel, glabrous. Fruiting pedicels: erect. Inflorescence: cymose-umbellate with few $(\leq 7)$ flowers. Flowers: $10 \mathrm{~mm}$ with white corolla fused at the base, petal length $2 x$ petal width; anthers yellow; styles usually not exserted; mature sepals: lanceolate, reflexed away from berries. Mature berries: $6-8 \mathrm{~mm}$ globose dark purple/black, very shiny, falling from calyces when ripe. Stone cells: usually absent. Cytology: $2 n=24$, diploid. 


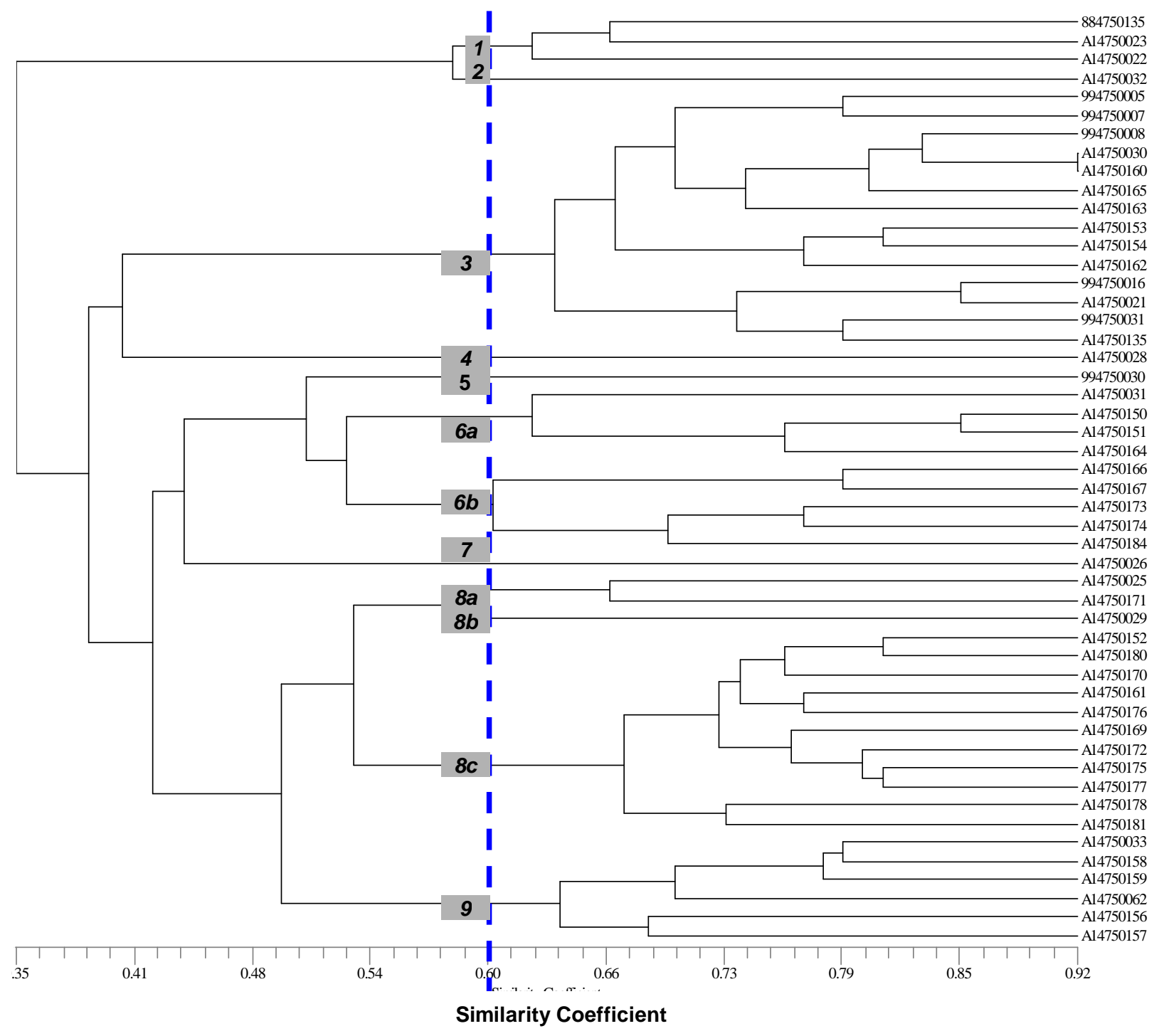

Figure 1: Clustering pattern of 50 African Solanum section Solanum accessions using morphological and cytological descriptors. The dotted line demarcates variation between (right) and within (left) species. 1: S. retroflexum; 2: $S$. grossidentatum; 3: S. scabrum; 4: S. americanum; 5: S. tarderemotum; 6: S. florulentum; 7: S. chenopodioides; 8: S. villosum; 9: S. nigrum. 


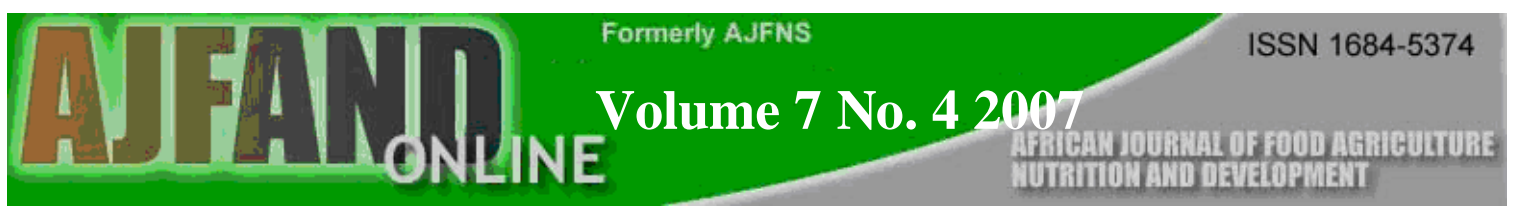

\section{Solanum chenopodioides Lam.}

Plants: up to $1.5 \mathrm{~m}$ high with erect tertiary level branches. Stem: greenish purple with small finely dented wings, densely pubescent with long eglandular hairs. Leaves: ovate-lanceolate with entire margins and acute apex, grayish green with light green veins, densely pubescent with eglandular hairs, petioles winged halfway, blade length $2 x$ blade width and $3 \times$ petiole lengths. Fruiting peduncle: deflexed, densely pubescent, $3 x$ longer than fruiting pedicel. Fruiting pedicel: reflexed. Inflorescence: a mixture of simple cymes and forked cymes on same plant, with few (5) to many (12 on forked cyme) flowers. Flowers: $12-14 \mathrm{~mm}$, corolla: white, fused below half-way, petal length 4x petal width; anthers: yellow; styles: exserted just beyond the anthers and straight; mature sepals: broadly triangular, adherent to berries, sepal length and width approximately equal. Mature berries: 7-9 mm, slightly flattened, black, dull, and remaining on plant when fully ripe. Stone cells: absent. Cytology: $2 n=24$, diploid.

\section{Solanum nigrum L.}

Plants: up to $1 \mathrm{~m}$ high with widely spreading tertiary level branches. Stems: purple with purple nodes, small to medium sized wings either prominently or finely dented, glabrous to sparsely pubescent with short eglandular appressed hairs when present. Leaves: ovate or lanceolate with entire sinuate or sinuatedentate finely lobed margins and acuminate to acute apices; grayish green to purple with greenish purple to purple veins; glabrous or sparsely pubescent with short, glandular appressed hairs when present. Fruiting peduncle: horizontal or facing upward, sparsely to densely pubescent, ranging from equal to $3 x$ pedicel length. Fruiting pedicel: reflexed. Inflorescence: either cymes, or a mixture of cymes and extended forked cymes on same plant, few (below 7) too many (above 20) flowered. Flowers: 11-14 mm; white corolla: fused either at the base or below halfway; petal length 2-3 times petal width; yellow anthers; styles: either exserted just beyond or not exserted, either curved or straight; mature sepals: triangular ovate or broadly triangular, usually reflexed away from (occasionally adherent to) berries, sepal length equal to or $2 x$ longer than wide. Mature berries: 8-12 $\mathrm{mm}$ slightly flattened to rounded, to dark-purple to black, usually dull, remaining on plant when fully ripe. Stone cells: absent. Cytology: $2 n=72$, hexaploid.

\section{Solanum retroflexum Dunal}

Plants: up to $0.7 \mathrm{~m}$ high with widely spreading erect branches, bushy. Stem:purplish green in color with green to purplish nodes, small wings along the stem with or without dents, densely pubescent, with long eglandular erect hairs. Leaves: ovate with clearly lobed dentate margins and acute to obtuse apices, 


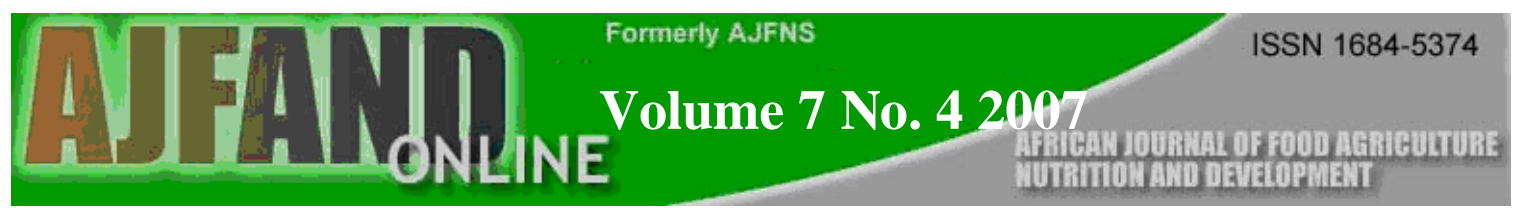

grayish green in color with light green or purplish veins, densely pubescent with short or long glandular erect hairs, petioles winged all the way, blade length equal to blade width, and $2 x$ petiole length. Fruiting peduncle : facing upward, densely pubescent, $2 x$ longer than fruiting pedicel. Fruiting pedicel: reflexed. Inflorescence: cymose, few to many flowered (7-13). Flowers: 11-13 mm, white corolla: fused half-way or below half-way, petal length $2 x$ petal width; anthers: yellow; styles: exserted clearly beyond the anthers and straight; mature sepals: either lanceolate or triangular-ovate, reflexed away from berries. Mature berries: 10-12 mm slightly flattened, dark purplish black with dull surface, remaining on plant when fully ripe. Stone cells either present or absent. Cytology: $2 n=48$, tetraploid.

\section{Solanum grossidentatum A.Richard}

Plant: up to $1 \mathrm{~m}$ high, widely spreading with extensively branched erect branches, bushy. Stem: green with green nodes, not winged, densely pubescent with long glandular erect hairs. Leaves: ovate-lanceolate with clearly lobed dentate margins and acute apices, grayish green in color with light green veins, densely pubescent with long glandular erect hairs. Fruiting peduncle: facing upward, densely pubescent and twice as long as fruiting pedicel. Fruiting pedicel: reflexed. Inflorescence: cymose, few flowered $(\leq 7)$.

Flowers: 12-14 mm, white corolla: fused below half-way, petal length $2 x$ petal width; anthers: yellow; styles: exserted clearly beyond the anthers, straight; mature sepals: lanceolate, $3 x$ as long as wide, adherent to berries. Mature berries: 8-11 mm, slightly flattened, yellowish green with dull surface, dropping with pedicels when ripe. Stone cells: present. Cytology: $2 n=48$, tetraploid.

\section{Solanum scabrum Miller}

Plants: up to $2 \mathrm{~m}$ high; erect, with primary and secondary branches (occasionally tertiary). Stem: and node color ranging from green to purplish green to purple with medium to prominent wings that are prominently dented; glabrous to sparsely pubescent with short eglandular, appressed or intermediate hairs where present. Leaves: ovate with entire to sinuate margins and acute (occasionally obtuse) apices, color ranging from light green to green, dark green and greenish purple, and vein color ranging from light green to purple; glabrous to sparsely pubescent with short, eglandular appressed to intermediate hairs where present; blade length equal to blade width and $2 x, 3 x$ or more times longer than petiole length, petiole winged half-way. Fruiting peduncle: facing upward, sparsely to densely pubescent and $3 x$ or more longer than fruiting pedicel. 


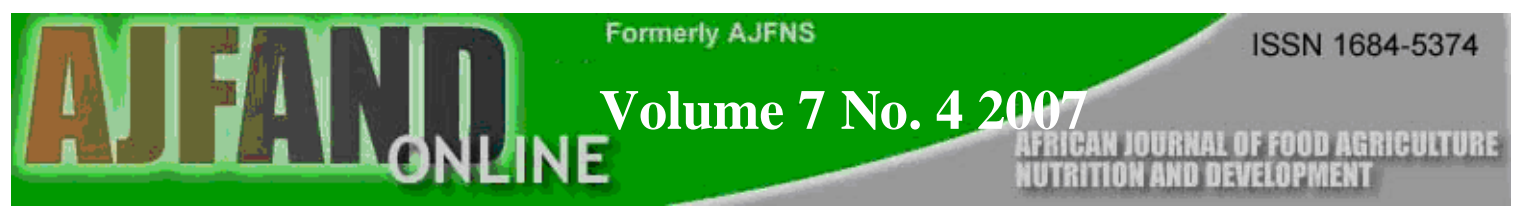

Fruiting pedicel: erect or reflexed. Inflorescence cymose-umbellate, many flowered (8-20). Flowers: large $\bullet 16 \mathrm{~mm}$, corolla: white or light purple and fused below half-way, petal length 2x petal width; anthers: yellow or brown; styles: not exserted or exserted either clearly or just beyond the anthers, either curved or straight; mature sepals: rounded in shape, reflexed away from berries, sepal length equal to width. Mature berries: large $(\cdot 16 \mathrm{~mm})$, slightly flattened, dark purplish black, shiny and remaining on plant when fully ripe. Stone cells: absent. Cytology: $2 n=72$, hexaploid.

\section{Solanum villosum Miller}

\section{subsp. miniatum (Bernh. ex Willd.) Edmonds}

Plants: up to $1 \mathrm{~m}$ high, spreading or erect, short branches to $3^{\text {rd }}$ level. Stem: green with node color ranging from green to purplish green to purple; small to medium sized wings $(1-2 \mathrm{~mm})$ either finely dented or not dented; glabrous to sparsely pubescent with short, eglandular appressed to intermediate hairs where present. Leaves: lanceolate to ovate with entire, sinuate, sinuate-dentate or dentate margins that may have clearly defined lobes or none, leaf apex acuminate to acute, light green to green lamina with light green or green veins; blade length either half as long or equal to blade width, and ranges from half as long to $3 x$ longer than petiole length; petiole winged all the way or half-way. Fruiting peduncle: facing upward, sparsely to densely pubescent, $3 x$ or more longer than fruiting pedicel. Fruiting pedicel: reflexed. Inflorescence: cymose, occasionally cymes mixed with forked cymes on same plant, few (7) to many flowered (above 20). Flowers: small $(<10 \mathrm{~mm})$, corolla: white fused either halfway or below half-way, petal length to width ratio ranging between 1 and 3; anthers: yellow; style: not exserted or exserted just beyond the anthers, straight where exserted; mature sepals: lanceolate (occasionally triangular-ovate), reflexed away from berries, sepal length 2 to 4 times sepal width. Mature berries: 7-9 $\mathrm{mm}$, higher rounded; orange; dull; remaining on plant when fully ripe. Stone cells: absent. Cytology: $2 n=48$, tetraploid.

\section{subsp. Villosum}

Plants: medium up to $1.2 \mathrm{~m}$ high with widely spreading erect branches, branched to tertiary level only. Stems: greenish purple with greenish purple nodes; small wings without dents, densely pubescent with long, glandular erect hairs. Leaves: ovate with finely lobed dentate margins and acute apex, greenish purple with light green veins; densely pubescent with long glandular erect hairs; blade length equal to blade width and $2 x$ petiole length, petioles winged all the way. Fruiting peduncle: densely pubescent, horizontal, $2 x$ as long as fruiting pedicel. Fruiting pedicel: reflexed. Inflorescence: cymose, few flowered $(<7)$. Flowers: 10-12 mm; 


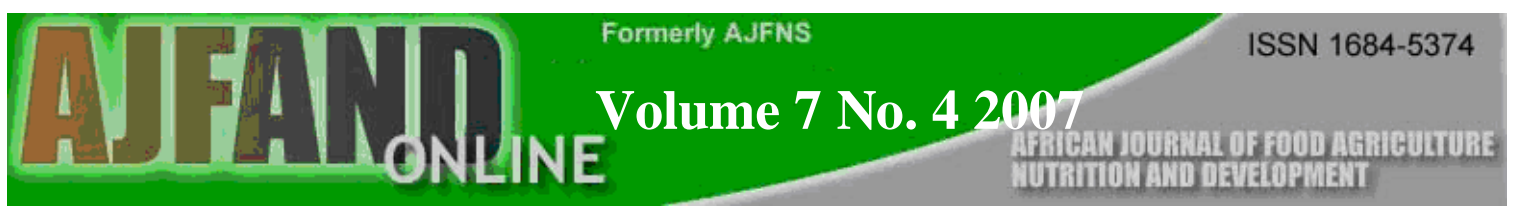

corolla: white, fused half-way, petal length equal to width; anthers: yellow; styles: clearly exserted beyond anthers, straight; mature sepals: triangular-ovate, reflexed away from berries, sepal length equal to width. Mature berries: 8-10 mm, globose; orange; dull; remaining on plant when fully ripe. Stone cells: absent. Cytology: $2 n=48$, tetraploid.

\section{Solanum tarderemotum Bitter}

Plants: up to $0.7 \mathrm{~m}$ high with spreading erect or prostrate branches. Stem: green to greenish purple with purplish nodes and small finely dented wings; glabrous to sparsely pubescent with short appressed eglandular hairs. Leaves: small to medium sized, lanceolate to ovate with entire margins and acuminate to acute apices; green with light green or purplish veins; sparsely pubescent with short, eglandular appressed to erect hairs; blade length $2 x$ blade width and $3 x$ to $4 x$ petiole length; petioles winged all the way or half-way. Fruiting peduncle: deflexed, horizontal or facing upward, sparsely to densely pubescent; twice as long as fruiting pedicel or more. Fruiting pedicel: reflexed. Inflorescence: extended mixed with (few) forked cymes many flowered (8-16). Flowers: small $(\bullet 11 \mathrm{~mm})$; corolla: white fused below half-way or at the base; petal length 2 to 3 times petal width; anthers: yellow; style: either exserted well beyond the anthers, curved or straight, or not exserted; mature sepals: lanceolate to ovate to broadly triangular, either reflexed or adherent to berries, sepal length equal or $2 x$ sepal length. Mature berries: $6-10 \mathrm{~mm}$, slightly flattened, occasionally rounded; light green or pinkish purple; dull; falling with pedicels when ripe. Stone cells present. Cytology: $2 n=48$, tetraploid.

\section{Solanum florulentum Bitter}

Plants: tall, up to $1.8 \mathrm{~m}$ high with erect branches branched to tertiary level only. Stem: green with greenish purple nodes and prominent wings that are prominently dented; sparsely pubescent with long eglandular intermediate hairs. Leaves: ovate-lanceolate with clearly lobed sinuate-dentate margins and acuminate apices; green with light green veins; sparsely pubescent with long eglandular intermediate hairs; blade length $2 x$ blade width and $3 x$ petiole length; petiole winged all the way. Fruiting peduncle: facing upward, sparsely pubescent, $3 x$ as long as fruiting pedicel. Fruiting pedicel: reflexed. Inflorescence: extended cymes, forked cymes or both mixed on same plant, many flowered (8-20). Flowers: 12-14 mm, corolla: white, fused below half-way; petal length 2x petal width; anthers: yellow; styles: exserted clearly beyond anthers and curved; mature sepals: broadly triangular, adherent to berries, sepal length equal to sepal width. Mature berries: $8-10 \mathrm{~mm}$, slightly flattened, dull dark purple; falling with pedicels when ripe. Stone cells: present. Cytology: $2 n=48$, tetraploid. 


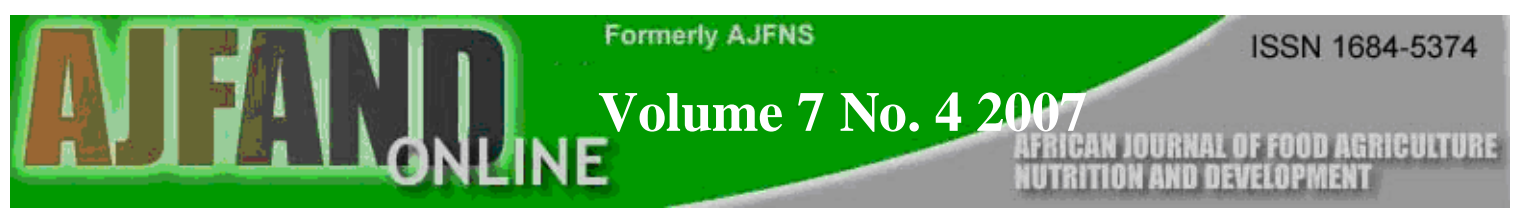

\section{DISCUSSION}

The tetraploid species Solanum retroflexum was represented by two phenotypes: two pubescent accessions with eglandular haired stems and glandular haired leaves; and one glabrous accession. Other than for the pubescence, the two phenotypes were identical. The great variation in the pubescence of $S$. retroflexum by has been recognized by Edmonds and Chweya and Jacoby et al $[8,19]$. Furthermore, these authors recognize two subspecies of S. villosum differentiated mainly by their pubescence. We hypothesize that the two $S$. retroflexum variants represent two subspecies distinguishable by pubescence [8, 20].

The identification and differentiation of Solanum florulentum and Solanum tarderemotum is still shrouded in confusion. Names that are used for these tetraploid species include Solanum eldorettii and Solanum eldoretianum. The name Solanum eldorettii was coined by Kilian Mtotomwema from Tanzania in 1987 without a proper description and without a publication, because he was of the opinion that the green berries characteristic of these plants do not fit within $S$. nigrum because the 'nigrum' epithet implied the plants should have black fruit. It is now clear, however, that these taxa belong in Solanum section Solanum. The taxa are reported to be popular leafy vegetables in several highland regions in East Africa including the Central, Rift Valley and Southwestern highlands in Kenya; Northern Tanzania and Southern Tanzania, and Ethiopia. It is probable that once they are better understood, they will also be found in other Eastern Africa regions [3].

The S. eldorettii-type accessions clustered together, although there is considerable morphological variation (Figure 1); with variants with green berries and others with purple berries; and extended cymose inflorescences or branched/forked cymes and yet others have intermediate characteristics with a mixture of simple and branched inflorescences on the same plant. Although recent attempts have been made to describe the variation within this group, the distinction between $S$. florulentum and $S$. tarderemotum (Table 2) is not yet clearly defined $[3,8,9,20]$. On going work at Radboud University Nijmegen, the Netherlands, is expected to shed insight into the morphological and genetic relationships and delimit these species.

Further investigations are needed to establish whether the highly variable subgroups observed in S. florulentum and S. villosum (cluster groups $6 \mathrm{a}, 6 \mathrm{~b}$ and $8 \mathrm{a}-$ 8c) (Figure 1) constitute single or several taxa. Molecular taxonomic techniques might be particularly helpful in this regard. Furthermore, since some species

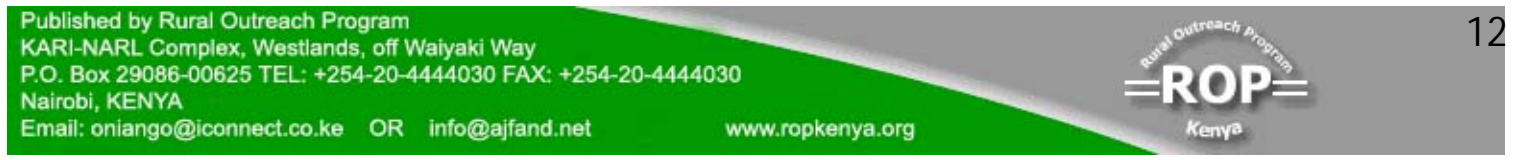




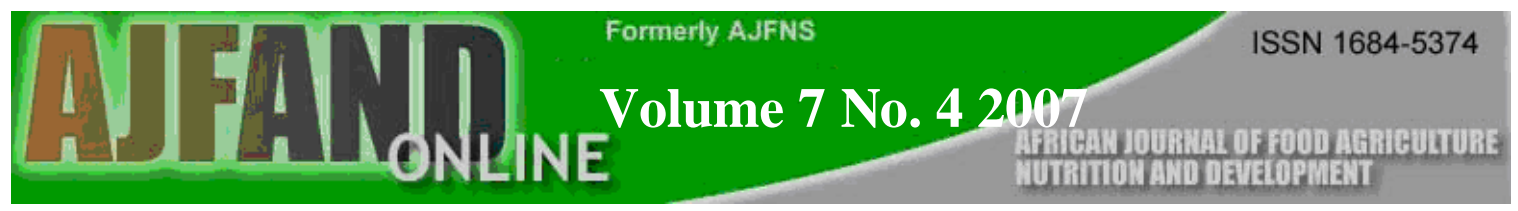

were represented by only one accession, the use of more extensive and representative germplasm collections is recommended to validate the current results.

\section{CONCLUSION}

This study documented the occurrence of nine Solanum section Solanum species in East, West and South Africa comprising a polyploid series with-: two diploids: Solanum americanum, and S. chenopodioides; five tetraploids: S. retroflexum, S. villosum, S. florulentum, S. grossidentatum and S. tarderemotum; and two hexaploids: $S$. nigrum and $S$. scabrum. Further studies, using a more comprehensive germplasm collection, are recommended to elucidate the taxonomic status of the $S$. florulentum/S. tarderemotum group as well as intraspecific variants of $S$. villosum, S. scabrum and S. retroflexum.

\section{ACKNOWLEDGEMENTS}

We acknowledge the collaboration of B. Tiomo, L. Manoko, G.M. van der Weerden, Titti Mariani and R.R. Schippers; and financial support from IPGRI's African Leafy Vegetables Programme. The assistance of staff at the Botanical and Experimental Garden, and Laboratory of Plant Cell Biology at Radboud Universityof Nijmegen; and the Institute for Research and Post-Graduate Studies (IRPS); Maseno University is also appreciated. 


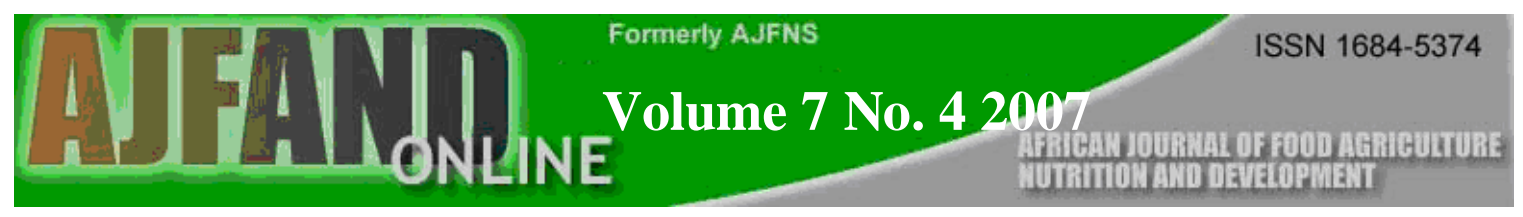

Table 1: Solanum section Solanum species represented in 50 African accessions

\begin{tabular}{|l|l|l|}
\hline Provisional name & Ploidy level & Number of accessions \\
\hline Solanum americanum & diploid & 1 \\
\hline Solanum chenopodioides & diploid & 1 \\
\hline Solanum grossidentatum & tetraploid & 1 \\
\hline Solanum retroflexum & tetraploid & 3 \\
\hline Solanum villosum & tetraploid & 14 \\
\hline Solanum florulentum & tetraploid & 8 \\
\hline Solanum tarderemotum & tetraploid & 2 \\
\hline Solanum nigrum & hexaploid & 6 \\
\hline Solanum scabrum & hexaploid & 14 \\
\hline
\end{tabular}

Table 2: Distinctive characters of nine African Solanum section Solanum species

\begin{tabular}{|c|c|}
\hline Species & Distinctive characters \\
\hline $\begin{array}{l}\text { Solanum } \\
\text { americanum }\end{array}$ & $\begin{array}{l}\text { - Berries shiny and globose when ripe, dropping from pedicels } \\
\text { - leaves and stems glabrous; stems semi-woody thin }\end{array}$ \\
\hline $\begin{array}{l}\text { Solanum } \\
\text { chenopodioides }\end{array}$ & $\begin{array}{l}\text { dull purplish black berries when ripe; don't drop from plant } \\
\text { - strongly reflexed peduncles in between nodes; stems and leaves } \\
\text { pubescent with eglandular hairs; semi-woody stems }\end{array}$ \\
\hline $\begin{array}{l}\text { Solanum } \\
\text { grossidentatum }\end{array}$ & $\begin{array}{l}\text { - } \quad \text { spreading plants; berries light-yellowish green, drop with pedicels } \\
\text { - stems and leaves covered by dense glandular hairs }\end{array}$ \\
\hline $\begin{array}{l}\text { Solanum } \\
\text { retroflexum }\end{array}$ & $\begin{array}{l}\text { - } \quad \text { spreading habit with strongly dentate leaf margins } \\
\text { - } \\
\text { - }\end{array}$ \\
\hline $\begin{array}{l}\text { Solanum } \\
\text { villosum }\end{array}$ & $\begin{array}{l}\text { - berries yellow-orange when ripe, don't drop or falling from pedicels } \\
\text { - leaves and stems densely pubescent or subglabrous }\end{array}$ \\
\hline $\begin{array}{c}\text { Solanum } \\
\text { nigrum }\end{array}$ & $\begin{array}{l}\text { - dark purple, slightly shiny/dull berries, dropping from pedicels } \\
\text { - leaves and stems green/purplish in colour, subglabrous }\end{array}$ \\
\hline $\begin{array}{l}\text { Solanum } \\
\text { scabrum }\end{array}$ & $\begin{array}{l}\text { - } \text { conspicuously larger plant parts (all) compared to other } \\
\text { nightshade species } \\
\text { - berries purple, shiny, large, don't drop } \\
\text { - } \text { stems with strongly dentate ridges }\end{array}$ \\
\hline $\begin{array}{l}\text { Solanum } \\
\text { florulentum }\end{array}$ & $\begin{array}{l}\text { - erect or spreading to prostrate; berries light green/ purple, drop } \\
\text { with pedicels; styles exserted; inflorescences extended or forked } \\
\text { cymes; berries purple } \\
\text { - stems and leaves subglabrous; leaves lanceolate }\end{array}$ \\
\hline $\begin{array}{l}\text { Solanum } \\
\text { tarderemotum }\end{array}$ & $\begin{array}{l}\text { - spreading plants with strongly dentate ridges; berries small (5- } \\
7 \mathrm{~mm} \text { ), light green or purple, dropping with pedicels }\end{array}$ \\
\hline
\end{tabular}




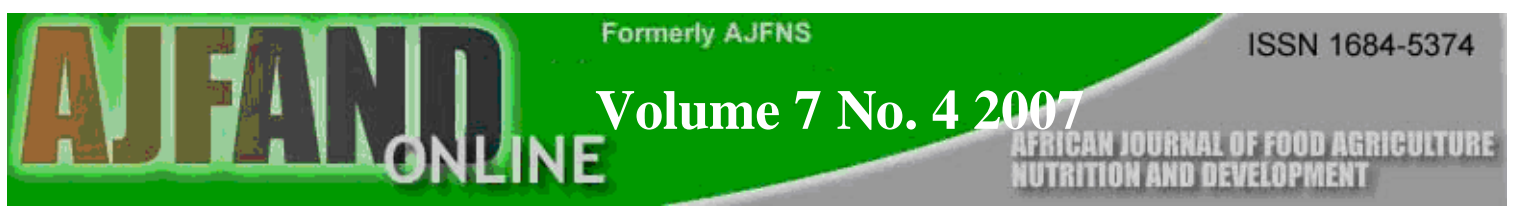

\section{REFERENCES}

1. Grubben $\mathbf{G}$ and $\mathbf{C}$ Almekinders Developing the potential of local vegetables using experiences from Africa and South-East Asia. A paper presented at a workshop on African indigenous vegetables; 13-18 January 1997. Limbe, Cameroon, 1997.

2. Guarino L (Ed) Traditional African Vegetables. Promoting the conservation and use of underutilized and neglected crops. 16. Proceedings of the IPRGRI International Workshop on Genetic Resources of Traditional Vegetables in Africa: Conservation and Use, 29-31 August 1995, ICRAF-HQ, Nairobi, Kenya. Institute of Plant Genetics and Crop Plant Research, Gatersleben/ International Plant Genetic Resources Institute. Rome, 1997.

3. Schippers RR African Indigenous Vegetables: an overview of the cultivated species. $2^{\text {nd }}$ revised edition on CD-Rom. Natural Resources Institute International, University of Greenwich and Horticultural Development Services LLP. Chatham, U.K, 2002.

4. Ruel MT, Minot $\mathbf{M}$ and $\mathbf{L}$ Smith Patterns and determinants of fruit and vegetables consumption in sub-Saharan Africa: A multi-country comparison. Background Paper for the Joint FAO/WHO Workshop on Fruit and Vegetables for Health. 1-3 September 2004. Kobe, Japan. The World Health Organization, 2005.

5. Chweya JA and PB Eyzaguirre (Eds) The Biodiversity of Traditional Leafy Vegetables. International Plant Genetic Resources Institute. Rome, 1999.

6. Schilling EE and $\mathbf{R N}$ Andersen The black nightshades (Solanum section Solanum) of the Indian subcontinent. Bot. J. Linn. Soc. 1990; 102: 253-259.

7. Onyango MA Effect of plant density and harvesting frequency on the yield and vegetable quality of four variants of black nightshade (Solanum nigrum L.). M.Sc. Thesis, University of Nairobi. Nairobi, 1993.

8. Edmonds JM and JA Chweya Black nightshade. Solanum nigrum L. and related species. Promoting the conservation and use of underutilized and neglected crops. 15. Institute of Plant Genetics and Crop Plant Research, Gatersleben/ International Plant Genetic Resources Institute. Rome, 1997.

9. Mwai GN and RR Schippers Solanum tarderemotum Bitter. In: Grubben GJH and OA Denton (Eds). Plant resources of Tropical Africa 2. Vegetables. 


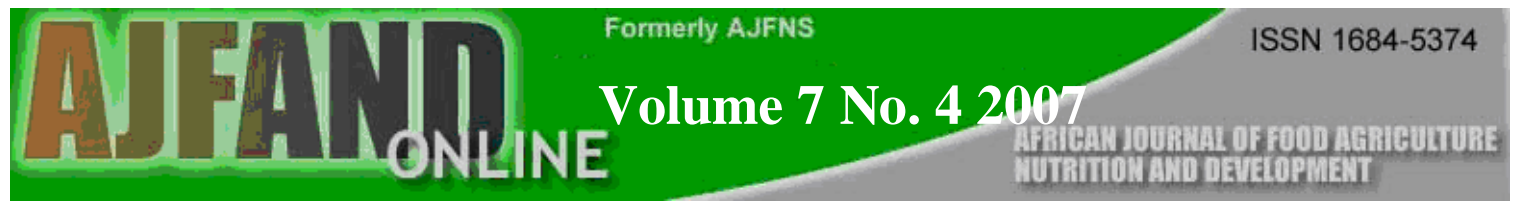

PROTA FOUNDATION, Wageningen, Netherlands/ Backhuys Publishers, Leiden, Netherlands/ CTA, Wageningen, The Netherlands, 2004: 498-501.

10. Maundu PM, Ngugi GW and CHS Kabuye Traditional Food Plants of Kenya. Kenya Resources Centre for Indigenous Knowledge, National Museum of Kenya. Nairobi, 1999.

11. Weinberger $\mathbf{K}$ and $\mathbf{J}$ Msuya Indigenous Vegetables in Tanzania-Significance and Prospects. Shanhua, Taiwan: AVRDC-The World Vegetable Center, Technical Bulletin No. 31, AVRDC Publication 04-600, 2004.

12. Edmonds JM Taxonomic studies on Solanum section Solanum (Maurella). Bot. J. Linn. Soc 1977; 75: 141-178.

13. Gray JM The taxonomy of the Morella section of the genus Solanum L. within South America. Ph.D. Thesis, University of Birmingham. UK, 1968.

14. Edmonds JM Numerical taxonomic studies on Solanum section Solanum (Maurella). Bot. J. Linn. Soc. 1978; 76: 27-51.

15. Heiser CB, Burton DL and EE Schilling Biosystematic and taxometric studies of the Solanum nigrum complex in eastern North America. In: Hawkes JG, Lester RN and AD Skelding (Eds). The Biology and Taxonomy of the Solanaceae. Academic Press, London, 1979: 513-527.

16. Jaeger PML Systematic studies in the genus Solanum L. in Africa. PhD thesis, University of Birmingham. UK, 1985.

17. Bukenya ZR and JF Carasco Solanum (Solanaceae) in Uganda. Bothalia 1985; 25(1): 45-59.

18. Bukenya ZR and JB Hall Solanum (Solanaceae) in Ghana. Bothalia 1988; 18(1): $79-88$.

19. Jacoby A, Labuschagne MT and CD Viljoen Genetic relationships between southern African Solanum retroflexum Dunal and other related species measured by morphological and DNA markers. Euphytica 2003; 132: 109113.

20. Olet EA, Heun M, and KA Lye African crop or poisonous nightshade; the enigma of poisonous or edible black nightshade solved. African Journal of Ecology 2005; 43: 158-161. 